\title{
ТРЕНІНГ ЯК ЕФЕКТИВНИЙ МЕТОД ПРАКТИЧНОЇ ПІДГОТОВКИ СТУДЕНТІВ-БІОЛОГІВ Фішук Оксана
}

\author{
Східноєвропейський національний університет імені Лесі Українки, \\ м. Луцьк, Україна, \\ dracaenaok@ukr.net
}

Модернізація освіти в Україні відповідно до сучасних вимог актуалізує дослідження тренінгової форми роботи для студентів різних спеціальностей. Розглянуто мету, завдання та переваги використання тренінгів у навчальному процесі. Фахівець у сфері біології має широкі можливості для працевлаштування (від лабораторій і садово-паркових господарств, до екологічного туризму). Найкращим методом для розвитку вузькоспеціалізованих професійних умінь (hard skills) та навичок міжособистісної взаємодіï (soft skills) для студента-біолога вважаємо тренінг. Запропоновано структуру навчального тренінгу для студентів-біологів. Описано основну мету, завдання й три тематичні блоки тренінгу: 1) спрямований на усвідомлення важливості професії, цілісного уявлення та формування адекватної реакції студентів до певного виду діяльності; 2) націлений на формування специфічних професійних умінь і навичок; 3) зорієнтований на усвідомлення учасниками себе в системі, яка стає частиною їхньої діяльності, та оптимізацію відносин до цієї системи. Описано застосування тренінгу на заняттях на тему: «Будова та функції квітки» для студентів-біологів як ефективного методу практичної підготовки. У тренінгу використано метод групового обговорення. Шляхом реалізації тренінгового заняття в межах курсу «Біоморфологія рослин» здійснено спробу розвитку в студентів-біологів hard skills (повторення й систематизація знань про будову квітки, іiі функції та будову плоду) i soft skills (уміння працювати в групі, налагоджувати міжособистісну взаємодію, розподіл обов'язків, визначення лідера). Перспективи дослідження вбачаємо в повноцінній розробці й апробації тренінгу для студентів-біологів.

Ключові слова: тренінг, студенти-біологи, освітній процес, hard skills, soft skills.

Fishchuk Oksana. Training as an Effective Method of Practical Training of Biological Students. Modernization of education in Ukraine in accordance with modern requirements actualizes the study of the training form of work for students of different specialties. The goals, tasks and advantages of using trainings in the educational process are considered. A specialist in the field of biology has ample employment opportunities (from laboratories and horticultural farms, to ecological

ISSN 2308-3743 (Online), ISSN 2227-1376 (Print)

(C) Фіщук О., 2020. Ця стаття відкритого доступу на умовах CC BY-NC 4.0 
tourism). We consider training as the best method for the development of highly specialized professional skills (hard skills) and skills of interpersonal interaction (soft skills) for a biology student. The structure of educational training for students of biologists is offered. The main purpose, tasks and three thematic blocks of training are described. The first is aimed to understanding the importance of the profession, a holistic view to a particular activity. The second is aimed to developing specific professional skills and abilities. The third is focused on the participants' awareness of themselves in the system that becomes part of their activities and the optimization of relations to this system. The use of training in classes on the topic: «Structure and functions of the flower» for biology students is described. In the training we used the method of group discussion. The training within the course «Plant Biomorphology» is aimed at developing biology students hard skills (repetition and systematization of knowledge about flower structure, flower functions and fruit structure) and soft skills (ability to work in a group, establish interpersonal interaction, division of responsibilities, definition leader). Prospects for the study are seen in the full development and testing of training for students of biology. skills.

Key words: training, biology students, educational process, hard skills, soft

\section{Фищук Оксана. Тренинг как эффективный метод практической} подготовки студентов-биологов. Модернизация образования в Украине в соответствии современным требованиям актуализирует исследования тренинговой формы работы для студентов различных специальностей. Рассматриваются цели, задачи и преимущества использования тренингов в учебном процессе. Специалист в области биологии имеет широкие возможности для трудоустройства (от лабораторий и садово-парковых хозяйств, к экологическому туризму). Лучшим методом для развития узкоспециализированных профессиональных умений (hard skills) и навыков межличностного взаимодействия (soft skills) для студента-биолога считаем тренинг. Предлагается структура учебного тренинга для студентов-биологов. Описываются основная цель, задачи и три тематических блока тренинга: 1) направлен на осознание важности профессии, целостного представления и формирования адекватной реакции студентов к определенному виду деятельности; 2) нацелен на формирование специфических профессиональных умений и навыков; 3) ориентирован на осознание участниками себя в системе, которая становится частью их деятельности, и оптимизацию отношений к этой системе. Описывается использование тренинга на занятиях на тему: «Строение и функции цветка» для студентов-биологов как эффективного метода практической подготовки. В тренинге использовался метод группового обсуждения. Путем реализации тренингового занятия в рамках курса «Биоморфология растений» мы предприняли попытку развития у студентов-биологов hard skills (повторение и систематизация знаний о строении цветка, функции цветка и строение плода) и soft skills (умение работать в группе, налаживать межличностное взаимодействие, распределение обязан- 
ностей, определение лидера). Перспективы исследования предусматриваем в полноценной разработке и апробации тренинга для студентов-биологов.

Ключевые слова: тренинг, студенты-биологи, образовательный процесс, hard skills, soft skills.

Постановка наукової проблеми та її значення. Період розвитку українського суспільства - це період активних змін, розбудови держави, інтеграції в європейську спільноту, що й визначає нові орієнтири щодо організації професійної підготовки майбутніх фахівців у вищих навчальних закладах України відповідно до європейських стандартів підготовки кваліфікованих фахівців усіх галузей. Одним з основних таких орієнтирів $\epsilon$ визначення соціально-психологічних основ професійного розвитку. У такі переломні моменти суспільство потребує зростання, досягнення внутрішньої свободи та усвідомлення гуманістичних ідеалів задля віри в краще майбутнє.

Багато сучасних досліджень у системі освіти спрямовано на розробку проблем удосконалення навчального процесу, для активізації суб'єкта навчання, збільшення частки його самостійності в оволодінні професійною діяльністю. Одним із перспективних та ефективних напрямів такої практично орієнтованої підготовки є застосування тренінгів у навчальному процесі для студентів-біологів. Проте на сьогодні в науці відсутне цілісне уявлення про те, як використовувати тренінг для формування компетентного біолога-професіонала. Тому набувають особливої актуальності питання, пов'язані з організацією тренінгів у навчальному процесі біологічних дисциплін як засобу розвитку професійно орієнтованого фахівця.

Аналіз останніх досліджень із цісї проблеми. Нині велику кількість праць відведено для розгляду різних аспектів застосування тренінгу в навчальному процесі. Багато дослідників підкреслюють актуальність його упровадження в сучасний навчальний процес для вивчення біологічних аспектів у підготовці студентів до майбутньої професійної діяльності (Скиба, 2016; Цуруль, 2017; Guidarelli, 2015; da Silva, Lago, Nery, Almeida, Tapety, Maia, da Silva, 2020). Деякі науковці пропагують необхідність тренінгового навчання протягом усього життя (Mampane, 2017).

Учені розрізняють так звані тренінги hard skills та soft skills (Laker, Powell, 2011). Тренінги hard skills мають вузькоспеціалізовану спрямованість, наприклад тренінги 3 права чи програмного забезпечення. Тренінги soft skills володіють більшим міжособистісним фо- 
кусом, наприклад тренінги спілкування чи лідерства (Jayaram, Musau, 2017).

У професійного навчання - дві основні цілі. Перша мета - сприяти навчанню в сенсі набуття нового знання та поведінки; друга сприяти подальшій передачі знань, тобто щоб слухачі були спроможні передати нові знання й поведінку на свої робочі місця та таким чином покращити власну роботу. Науковці C. Bonnes i S. Hochholdinger обгрунтовують думку про необхідність використання тренінгів у професійному навчанні (Bonnes, Hochholdinger, 2020).

У психології тренінг переважно розуміється як «активний метод групової психологічної роботи задля розвитку комунікативної компетентності в спілкуванні», а також як «засіб психологічного впливу». Мета тренінгу конкретизується залежно від його спрямованості, але обов'язково вказує на набуття знань, умінь і навичок, формування установок, що визначають поведінку в спілкуванні, відображають перцептивні здібності людини, спрямовані на корекцію й розвиток системи відносин особистості (Ушатова, 2012: 11).

М. Р. Битянова підкреслює, що тренінг у навчальному процесі повинен застосовуватися з урахуванням таких умов: для всієї навчальної групи; в обов'язковому порядку; у режимі коротких зустрічей раз на тиждень; у ситуації з досить низькою психологічною безпекою, характерною для навчальних закладів (Битянова, 1995).

Поняття «навчально-професійний тренінг» уперше з'явилося в рамках контекстного підходу до навчання (А. А. Вербицький) і трактується як вид навчальних занять, призначений для навчально-професійної діяльності студентів, зміст якої формується, виходячи 3 логіки не лише досліджуваного предмета, а й майбутньої професійної діяльності (Вербицький, 1991). У професійному навчанні акцентовано на отриманні практичних знань, утіленні та передачі знань (Stevenson, 2012).

Навчальний тренінг у професійній підготовці майбутніх фахівців розглядають із декількох ракурсів: тренінговий метод навчання; спосіб спільної діяльності вчителя й учнів, що передбачає оволодіння соціальним досвідом людства та керівництво навчально-пізнавальною діяльністю школярів із боку вчителя; засіб і шлях (упорядкована дія) із метою одержання певного результату в процесі навчально-виховної роботи; спосіб навчання; системний метод створення, застосування й визначення всього процесу навчання й засвоєння знань 3 
урахуванням технічних і людських ресурсів та їх взаємодії, що ставить своїм завданням оптимізацію освіти (Сікора, 2011: 121-122).

Дослідник О. М. Кочерга досліджував особливості застосування тренінгових технологій у процесі формування практичної компоненти професійної підготовки майбутніх учителів. Він вважає, що в ході тренінгу майбутні вчителі мають можливість практикуватись, експериментувати, моделювати ситуацію, перевіряти свої висновки, аналізувати досягнення, шліфувати навички спілкування й власну поведінку. Це дає змогу уникнути помилок у реальних умовах, допомагає швидше приймати оптимальні рішення та долати труднощі в подальшій професійній діяльності (Кочерга, 2014: 119).

Професійний тренінг, на думку А. К. Маркової, - «це система впливів, вправ, які спрямовані на розвиток, формування, корекцію в людині необхідних професійних якостей. Функціями тренінгу є перетворювальна, коректувальна та профілактична» (Маркова, 1996: 236).

Завдання професійного тренінгу визначаються в межах формування цілісної особистості суб'єкта праці; формування окремих видів професійної діяльності або професійного спілкування; розвиток мотиваційної сфери як пошук нових мотивів і нової системи цілей професійної діяльності; формування емоційної сфери, технік володіння емоційними станами в професійній діяльності; посилення операційної сфери як володіння новими професійними техніками. Усі ці завдання тренінгу розвивають уміння взаємодіяти з іншими людьми в процесі праці (професійне співробітництво); підвищують професійний та соціальний статус; посилюють готовність працівника до інновацій; стимулюють процес усвідомлення професійних завдань майбутнього віку, потреби й здатності індивідуального самовираження в праці; спонукає до процесу постійного професійного самовдосконалення та саморозвитку, перевірки ефективності різних стратегій професійного зростання й ін. (Маркова, 1996: 236-237).

Стосовно процесу професійної підготовки в організаційному аспекті тренінг розглянуто як групову форму організації процесу навчання (виду навчального заняття) у вищій школі з професійною, практико-орієнтованою метою. Таке розуміння цілком співвідносне 3 основним значенням тренінгу: «Training - the process of bringing a person to an agreed standard of proficiency by practice and instruction» (Collins English Dictionary, 2000: 304). Навчальна група студентів при цьому стає навчально-тренувальною групою, де поєднуються лекцій- 
на підготовка та тренувальні вправи 3 подальшим аналізом ситуацій, що виникають у ході їх виконання (Большаков, 1995: 30).

Формулювання мети та завдань статті. Актуальність і недостатня розробленість представленої проблеми зумовили вибір мети статті - здійснити теоретичний аналіз особливостей застосування тренінгу на заняттях із біології, його переваг та запропонувати орієнтовну програму такого тренінгу для студентів із предмету «Біоморфологія рослин».

Виклад основного матеріалу й обгрунтування отриманих результатів дослідження. Програма тренінгу для студентів-біологів полягає в забезпеченні конкурентоспроможності випускника вищого навчального закладу. Конкурентоспроможність фахівця на сучасному ринку праці пов'язується не стільки з інформаційним і технологічним ресурсами спеціаліста, скільки з його здібностями до постійного професійного самовдосконалення, виконання професійної діяльності творчо, перетворюючи, удосконалюючи і професійне середовище, i способи професійної діяльності та створюючи таким чином нові професійні цінності. Закордонні науковці пропонують запроваджувати тренінги вже 3 першого курсу для інтеграції й адаптації студента до університету та спільноти (Apiñaniz-Fernandez de Larrinoa E. et al, 2017).

Практична підготовка студента зазвичай обмежується проходженням практики в межах навчальних планів. В Україні така практика зазвичай займає 2-3 тижні й відбувається на 4-му та 5 курсах навчання. Такий досвід практичної діяльності не дає достатньо знань і вмінь для становлення професіонала. Саме тому в межах навчання у ВНЗ ми пропонуємо застосовувати тренінги професійного становлення для студентів-біологів.

Тренінг розглянуто як активний метод групового навчання, спрямований на формування професійної спрямованості та компетентності, соціально й професійно значущих якостей, готовність до постійного професійного саморозвитку, пошук оптимальних прийомів якісного та творчого виконання діяльності відповідно до індивідуальнопсихологічних особливостей людини.

Цінним моментом у використанні тренінгу є те, що він дає змогу організувати такий особливий освітній простір, у якому майбутні фахівці-біологи усвідомлюють власну некомпетентність щодо вирішення змодельованої ситуації, визначаються з власними обмеження- 
ми в наявних знаннях чи компетенціях, емоційно переживають їх, що, урешті, спонукає до дії: студенти роблять спроби знайти альтернативні варіанти виходу з уявної ситуації, оптимальні способи виконання поставлених завдань. Завдяки цьому особистість накопичує професійний досвід, яким керується в подальших аналогічних реальних ситуаціях під час виконання професійних завдань як у ході практики, так $\mathrm{i}$ в подальшій професійній діяльності.

Перевагою тренінгу для студентів-біологів, порівняно з традиційним практичним заняттям, є те, що він відбувається в психологічно комфортному середовищі, тобто дає змогу студентам проявляти активність, практично відпрацьовувати досліджуваний матеріал, формувати й розвивати навички спілкування, самопізнання, рефлексії та самооцінки. Отже, навчальні тренінги, крім дидактичних завдань, реалізовують і психологічні, що робить їх використання на сьогодні особливо актуальним у процесі навчання студентів у ВНЗ. За допомогою тренінгової форми роботи студенти можуть розвинути так звані soft skills (м'які навички), які стосуються спілкування та ефективної взаємодії з іншими й відповідного тлумачення різних соціальних ситуацій (Dell'Aquila, Marocco, Ponticorvo, di Ferdinando, Schembri, Miglino, 2017: 3).

Проведення навчальних тренінгів для студентів-біологів спрямоване на формування й утвердження особливого світогляду, цінностей та способу життя, сприяє вихованню бережного ставлення до живих істот, альтруїзму й поваги як до людей, так і до природи. Тому майстерність і професіоналізм біолога передбачає постійне вдосконалення не лише ключових знань та компетентностей, а й практичних навичок і прийомів.

Біолог - це спеціаліст, який досліджує закономірності розвитку живих організмів та їхні функції й властивості, вивчає різноманітність рослинного та тваринного світу. Він озброєний знаннями збору матеріалу та можливостей його дослідження, організації експериментів і практичного застосування отриманих результатів. На біологічному факультеті наявні спеціалізації, студент обирає напрям досліджень, наприклад зоологія, де вивчається анатомія та фізіологія тварин, закономірності розвитку й особливості поведінки, видова різноманітність тварин; ботаніка вивчає будову, життєдіяльність розмноження, історію розвитку, поширення та класифікацію рослин, грибів і водоростей; анатомія та фізіологія розкривають будову людини та 
особливості їі життедіяльності, аномальний розвиток окремих органів й організму в цілому. Науково-дослідна та методична робота вимагає від студента-біолога аналітичного й логічного мислення, старанної та відповідальної роботи в лабораторії чи на практиці в природі. А робота в галузі освіти, виховання, а також соціальної спрямованості комунікабельності й ораторської майстерності. Він повинен бути терплячим, доброзичливим, чуйним, уміти уважно вислухати, заохотити та оцінити учнів.

Також фахівець у галузі біології може працювати в науководослідних установах, лабораторіях й садово-паркових господарствах, технологічних харчових підприємствах та установах екологічного контролю. Володіючи іноземними мовами, біолог може реалізувати себе у сфері екологічного туризму. Біологи також працюють у державних організаціях, де ключовими функціями є моніторинг й оцінка рослинних насаджень.

Мета тренінгу - формування в учасників тренінгу практичних професійних навичок і вмінь; вироблення навичок співпраці, становлення студента як біолога, викладача біології, професіонала.

Основними завданнями тренінгу для студентів-біологів $\epsilon$ :

1) формування в студентів системи уявлень щодо психологічного, соціального й педагогічного змісту професійної діяльності;

2) формування мотиваційно-ціннісної професійної спрямованості особистості студентів, через аналіз та переоцінку власного життєвого досвіду в процесі групової взаємодії;

3) згуртування навчального колективу студентів;

4) формування вмінь і навичок, необхідних для планування та успішної реалізації кар'єри в галузі освіти, для біологів це комунікативні, організаторські вміння й навички міжособистісної взаємодії;

5) моделювання ситуації, для актуалізації усвідомлення та переживання особливостей професійної діяльності;

6) вироблення кожним учасником (студентом) свого професійного стилю, усвідомлення своїх професійних можливостей, визначення шляхів професійного зростання.

7) формування вмінь і навичок у студентів-біологів як постійного бажання до саморозвитку, творчості та постійного самовдосконалення в професійній сфері.

Тренінг запропоновано проводити протягом 3-4 курсу навчання, коли етап адаптації до вузівського середовища закінчився й роз- 
почався процес цілеспрямованого засвоєння соціально та професійно значимого досвіду.

Тренінг містить три тематичні блоки. Перший спрямовано на усвідомлення важливості професії, цілісного уявлення й формування адекватної реакції студентів на певний вид діяльності. Також цей блок націлено на формування вмінь установлювати міжособистісні стосунки з навколишніми, а головне - із членами академічних груп, їх оптимізації, створення ціннісно-орієнтаційної єдності групи, для формування комфортних умов співпраці не лише на тренінгових заняттях, а й у процесі всього процесу навчання на біологічному факультеті у ВНЗ. У цьому блоці активно застосовують вправи на командоутворення, групові дискусії тощо.

Другий блок сприяє формуванню вмінь та навичок. Особливу увагу приділяють розвитку практичних можливостей особистості, іiі соціально-перцептивних і комунікативних здібностей, усвідомленню звичних способів спілкування, аналізу помилок у міжособистісній взаємодії й розвитку організаційних умінь. Великого значення в цьому блоці надають системі відпрацювання навичок оптимального спілкування. Учасники групи ознайомлюються 3 прийомами налагодження ділової взаємодії та спілкування з колегами на роботі, з адміністрацією, діловими партнерами. Цим цілям слугує використання рольових та організаційно-діяльнісних ігор. Тренінгові ігри мають великий мотиваційний потенціал. Їх розроблено, щоб сприяти залученню користувачів, і ця участь також є ключовим прогнозом успіху в будь-якій освіті чи тренінговій програмі (Dell'Aquila, Marocco, Ponticorvo, di Ferdinando, Schembri, Miglino, 2017: 40).

Третій блок орієнтований на усвідомлення учасниками себе в системі, яка стає частиною їхньої діяльності, й оптимізацію відносин до цієї системи. На цьому етапі основний акцент робиться на закріплення нових поведінкових патернів, відпрацювання вмінь самоаналізу, а також способи вивільнення свого творчого потенціалу. У цьому блоці необхідне формування зворотного зв'язку за тематикою тренінгу як інтегрального утворення особистості, що складається 3 ціннісного компонента, творчості та креативності й прагнення до досягнення поставленої мети, вихід за межі індивідуальної особи. У цьому блоці учасники тренінгу знайомляться з короткими та ефективними способами зняття внутрішньої напруги, прийомами саморегуляції. 
Нами розроблено тренінгове заняття для студентів-біологів 4 курсу для дисципліни «Біоморфологія рослин», зокрема на тему: «Будова та функції квітки». Метою викладання навчальної дисципліни $\epsilon$ ознайомлення студентів із різноманіттям життєвих форм вищих рослин, 3 екологічними умовами їх розвитку, із декоративністю життєвих форм і можливістю їх застосування у фітодизайні.

Згідно з вимогами освітньо-професійної програми, студенти повинні знати будову та функції рослин, різноманітні підходи до класифікації життєвих форм; характерні особливості життєвих форм за класифікацією Раункієра й Серебрякова; роль середовища у формуванні життєвих форм; уміти аналізувати біоморфний склад рослинних угруповань; виявляти декоративні особливості життєвих форм; оцінювати можливість їх використання у фітодизайні.

На тренінговому практичному занятті перевагу надають діяльності студента, особистий досвід якого є основою для подальшого навчання. Студенти обмінюються інформацією, котрою володіють на цей момент, і самі знайдуть інформацію, якої їм не вистачає для повного висвітлення тієї чи іншої теми. Викладач пояснює актуальність обраної теми тренігу студентам та вказує мету й способи ії досягнення.

Для нашого тренінгу використано метод групового обговорення, вивчення та дослідження чогось нового. Метою застосування цього методу $є$ продуктивна, результативна командна робота, тобто за допомогою спеціальних засобів студенти можуть ефективно за групами засвоювати новий і повторювати раніше вивчений матеріал.

Ми розділили академічну групу студентів на три приблизно однакові групи. Кожній із них роздано по аркушу паперу та маркеру. Кожна група окремо на аркуші описувала будову квітки, зокрема малювала іiі та робила підписи органів квітки, використовуючи іменники; функції квітки - дієсловами й будову плоду - рисунками та підписами, іменниками. Студенти активно включилися до написання дієслів й іменників і спілкувалися та обмінювались ідеями між собою. На написання слів їм давалося 15 хвилин.

Кожна група обрала людину, котра представляє проект (лідера), повісивши свій список на дошці й озвучивши обрані дієслова та іменники, пояснюючи, чому саме їх застосувала група. Після того, як вислухали представників усіх трьох груп, хтось із студентів узагальнить вивчений на занятті матеріал і виступить біля дошки, узагальнивши у своїй промові всі дієслова й іменники на трьох плакатах. Так 
у формі гри та спілкування між собою студенти можуть легко вивчити, повторити й засвоїти новий матеріал.

Висновки й перспективи подальших досліджень. Здійснений теоретичний аналіз використання тренінгу як методу активного навчання для студентів продемонстрував його значний потенціал. Тренінгові методи дають змогу розвинути навички практичної діяльності та виходу з проблемної ситуації в професійній сфері. Крім того, тренінг створює можливості для розвитку так званих soft-skills (м'яких навичок), тобто вміння домовлятися, працювати в групі, організовувати роботу.

Практико-орієнтована професійна підготовка студентів-біологів, здійснена в умовах тренінгу як виду навчальних занять, сприяє формуванню професійно-комунікативних умінь, становленню професіонала, готового в реальних умовах науково, якісно та ефективно виконувати свої функції. Описано практику реалізації тренінгового заняття для студентів-біологів на тему «Будова та функції квітки». Шляхом проведення тренінгового заняття в межах курсу «Біоморфологія рослин» здійснено спробу розвитку в студентів-біологів hard skills (повторення й систематизації знань про будову квітки, іiі функції та будову плоду) i soft skills (уміння працювати в групі, налагоджувати міжособистісну взаємодію, розподіл обов'язків, визначення лідера). Перспективи дослідження вбачаємо в повноцінній розробці й апробації тренінгу для студентів-біологів.

\section{Література}

1. Большаков, В. Ю. (1996). Психотренинг: соџиодинамика. Упражнения. Игры. Санкт-Петербург.

2. Битянова, М. Р. (1995). Психология личностного роста. Москва: Междунар. пед. академия.

3. Вербицкий, А. А. (1991). Активное обучение в высшей школе: контекстный подход. Москва: Высш. шк.

4. Кочерга, О. М. (2014). Особливості використання тренінгових технологій у процесі формування практичної компоненти професійної підготовки майбутнього учителя. Молодий вчений, 2 (05), 116-119.

5. Сікора, Я. Б. (2011). Використання тренінгів у професійній підготовці компетентних фахівців з інформатики. Психолого-педагогічні проблеми сільської школи: зб. наук. праць Уманського держ. пед. ун-ту ім. Павла Тичини, 36, $115-121$.

6. Скиба, М. (2016). Формування умінь еколого-педагогічної діяльності майбутніх учителів біології у процесі тренінгу. Педагогічний процес: теорія $i$ практика. Серія: Педагогіка, 4 (55), 124-129. 
7. Маркова, А. К. (1996). Психология профессионализма. Москва: Междунар. гуманитарный фонд «Знание».

8. Ушатова, И. В. (2012). Учебно-профессиональный тренинг как средство подготовки будущих педагогов профессионального обучения: автореф... канд. психол. наук. Москва: ФГБОУ ВПО МГАУ.

9. Цуруль, О. А. (2017). Методика організації та проведення семінарів: особливості підготовки майбутніх учителів біології. Педагогічні науки: теорія, історія, інноваиійні технології: наук. журн., 9 (73), 130-140.

10. Apiñaniz-Fernandez de Larrinoa, E. et al. (2017) Welcome Program for First Year Students at the Faculty of Engineering of Vitoria-Gasteiz. Soft Skills. In: Graña M., López-Guede J., Etxaniz O., Herrero Á., Quintián H., Corchado E. (eds) International Joint Conference SOCO'16-CISIS'16-ICEUTE'16. SOCO 2016, CISIS 2016, ICEUTE 2016. Advances in Intelligent Systems and Computing, 527. Springer, Cham. https://doi.org/10.1007/978-3-319-47364-2_69

11. Bonnes, C., Hochholdinger, S. (2020). Approaches to Teaching in Professional Training: a Qualitative Study. Vocations and Learning. https://doi.org/ 10.1007/s12186-020-09244-2

12. Collins English Dictionary. Intense Educational. Ltd., 2000.

13. Dell'Aquila, E., Marocco, D., Ponticorvo, M., di Ferdinando, A., Schembri, M., Miglino, O. (2017). Educational Games for Soft-Skills Training in Digital Environments. New Perspectives. Switzerland: Springer. DOI: https://doi.org/10. 1007/978-3-319-06311-9

14. Guidarelli, L. (2015). Professional training and research: which resources? Italian Journal of Pediatrics, 41(Suppl 2): A41. DOI: https://doi.org/10.1186/18247288-41-S2-A41

15. Jayaram, S., Musau, R. (2017). Soft Skills: What They Are and How to Foster Them. Bridging the Skills Gap, Technical and Vocational Education and Training: Issues, Concerns and Prospects, 26, 101-122. DOI: https://doi.org/10.1007/978-3319-49485-2_6

16. Laker, D. R., \& Powell, J. L. (2011). The differences between hard and soft skills and their relative impact on training transfer. Human Resource Development Quarterly, 22, 111-122. DOI: https://doi.org/10.1002/hrdq.20063

17. Mampane, S. T. (2017). Professional Training and Lifelong Learning for School Heads of Departments: A Gateway for Headship Continuous Improvement. In: Amzat I., Valdez N. (eds) Teacher Empowerment Toward Professional Development and Practices. Springer, Singapore. DOI: https://doi.org/10.1007/978981-10-4151-8_8

18. Stevenson, J. C. (2012) Vocational Learning. In: Seel N.M. (eds) Encyclopedia of the Sciences of Learning. Springer, Boston, MA. DOI: https://doi.org/10.1007/978-1-4419-1428-6

19. da Silva, M. N. P., Lago, E. C., Nery, I. S., Almeida, C. A. P. L., Tapety, F. I. Maia, A. B. B., \& da Silva, E. S. (2020). Elderly health: professional training and performance in primary health care. Bioscience Journal, 36(4). https://doi.org/10. 14393/BJ-v36n4a2020-42688 


\section{References}

1. Bol'shakov, V. Ju. (1996). Psihotrening: Sociodinamika Uprazhnenija [Psychotraining: Sociodynamics. Exercises]. Igry. Sankt-Peterburg (in Russian).

2. Bitjanova, M. R. (1995). Psihologija lichnostnogo rosta [Psychology of personal growth]. M. Mezhdunarodnaja pedagogicheskaja akademija (in Russian).

3. Verbickij, A. A. (1991). Aktivnoe obuchenie v vysshej shkole: kontekstnyj podhod [Active learning in higher education: a contextual approach]. Moskva: Vysshaja shkola (in Russian).

4. Kocherha, O. M. (2014). Osoblyvosti vykorystannia treninhovykh tekhnolohii $\mathrm{u}$ protsesi formuvannia praktychnoi komponenty profesiinoi pidhotovky maibutnoho uchytelia [Features of the use of training technologies in the process of forming a practical component of professional training of future teachers]. Molodyi vchenyiYoung Scientist, 2 (05), 116-119 (in Ukrainian).

5. Sikora, Ya. B. (2011). Vykorystannia treninhiv u profesiinii pidhotovtsi kompetentnykh fakhivtsiv z informatyky [Use of trainings in professional training of competent specialists in informatics]. Psykholoho-pedahohichni problemy silskoi shkoly: zbirnyk naukovykh prats Umanskoho derzhavnoho pedahohichnoho universytetu imeni Pavla Tychyny - Psychological and pedagogical problems of rural school: collection of scientific works of Uman State Pedagogical University named after Pavel Tychyna, 36, 115-121 (in Ukrainian).

6. Skyba, M. (2016). Formuvannia umin ekoloho-pedahohichnoi diialnosti maibutnikh uchyteliv biolohii u protsesi treninhu [Formation of skills of ecological and pedagogical activity of future biology teachers in the process of training]. Pedahohichnyi protses: teoriia $i$ praktyka (seriia: pedahohika) - Pedagogical process: theory and practice (series: pedagogy), 4 (55), 124-129 (in Ukrainian).

7. Markova, A. K. (1996). Psihologija professionalizma [The psychology of professionalism]. Moskva: Mezhdunarodnyj gumanitarnyj fond «Znanie» (in Russian).

8. Ushatova, I. V. (2012). Uchebno-professional'nyj trening kak sredstvo podgotovki budushhih pedagogov professional'nogo obuchenija [Educational and professional training as a means of preparing future teachers of vocational training]. Extended abstract of candidate's thesis. Moskva: FGBOU VPO MGAU (in Russian).

9. Tsurul, O. A. (2017). Metodyka orhanizatsii ta provedennia seminariv: osoblyvosti pidhotovky maibutnikh uchyteliv biolohii [Methods of organizing and conducting seminars: features of training future biology teachers]. Pedahohichni nauky: teoriia, istoriia, innovatsiini tekhnolohii: nauk. zhurnal - Pedagogical sciences: theory, history, innovative technologies: sciences. journal, 9 (73), 130-140 (in Ukrainian).

10. Apiñaniz-Fernandez de Larrinoa, E. et al. (2017) Welcome Program for First Year Students at the Faculty of Engineering of Vitoria-Gasteiz. Soft Skills. In: Graña M., López-Guede J., Etxaniz O., Herrero Á., Quintián H., Corchado E. (eds) International Joint Conference SOCO'16-CISIS'16-ICEUTE'16. SOCO 2016, CISIS 2016, ICEUTE 2016. Advances in Intelligent Systems and Computing, 527. Springer, Cham. https://doi.org/10.1007/978-3-319-47364-2_69 
11. Bonnes, C., Hochholdinger, S. (2020). Approaches to Teaching in Professional Training: a Qualitative Study. Vocations and Learning. https://doi.org/ 10.1007/s12186-020-09244-2

12. Collins English Dictionary. Intense Educational. Ltd., 2000.

13. Dell'Aquila, E., Marocco, D., Ponticorvo, M., di Ferdinando, A., Schembri, M., Miglino, O. (2017). Educational Games for Soft-Skills Training in Digital Environments. New Perspectives. Switzerland: Springer. DOI: https://doi.org/10. 1007/978-3-319-06311-9

14. Guidarelli, L. (2015). Professional training and research: which resources? Italian Journal of Pediatrics, 41(Suppl 2): A41. DOI: https://doi.org/10.1186/18247288-41-S2-A41

15. Jayaram, S., Musau, R. (2017). Soft Skills: What They Are and How to Foster Them. Bridging the Skills Gap, Technical and Vocational Education and Training: Issues, Concerns and Prospects, 26, 101-122. DOI: https://doi.org/10.1007/978-3319-49485-2_6

16. Laker, D. R., \& Powell, J. L. (2011). The differences between hard and soft skills and their relative impact on training transfer. Human Resource Development Quarterly, 22, 111-122. DOI: https://doi.org/10.1002/hrdq.20063

17. Mampane, S. T. (2017). Professional Training and Lifelong Learning for School Heads of Departments: A Gateway for Headship Continuous Improvement. In: Amzat I., Valdez N. (eds) Teacher Empowerment Toward Professional Development and Practices. Springer, Singapore. DOI: https://doi.org/10.1007/978981-10-4151-8_8

18. Stevenson, J. C. (2012) Vocational Learning. In: Seel N. M. (eds) Encyclopedia of the Sciences of Learning. Springer, Boston, MA. DOI: https://doi.org/ 10.1007/978-1-4419-1428-6

19. da Silva, M. N. P., Lago, E. C., Nery, I. S., Almeida, C. A. P. L., Tapety, F. I. Maia, A. B. B., \& da Silva, E. S. (2020). Elderly health: professional training and performance in primary health care. Bioscience Journal, 36(4). https://doi.org/10. 14393/BJ-v36n4a2020-42688

Received: 21.01 .2020

Accepted: 13.02.2020 